\title{
Effect of Amylolytic and Cellulolytic Enzymes on Whole Plant Corn Silage: Characteristics of Silage and Animal Digestion
}

JEFFERSON RODRIGUES GANDRA ( $\sim$ jeffersongandra@unifesspa.edu.br )

Universidade Federal do Sul e Sudeste do Para https://orcid.org/0000-0002-4134-5115

\section{Alanne T. Nunes}

USP FMVZ: Universidade de Sao Paulo Faculdade de Medicina Veterinaria e Zootecnia

\section{Euclides R. Oliveira}

UFGD: Universidade Federal da Grande Dourados

\section{Mávio S. J. Silva}

UFGD: Universidade Federal da Grande Dourados

\section{Cibeli A. Pedrini}

UFGD: Universidade Federal da Grande Dourados

\section{Fabio S. Machado}

UFGD: Universidade Federal da Grande Dourados

\section{Geleice K. R. Silva}

UFGD: Universidade Federal da Grande Dourados

\section{Erika R. S. Gandra}

UFGD: Universidade Federal da Grande Dourados

\section{Paulo V. C. Mendes}

UNIFESSPA: Universidade Federal do Sul e Sudeste do Para

\section{Alzira G. S. Pause}

UNIFESSPA: Universidade Federal do Sul e Sudeste do Para

\section{Research Article}

Keywords: aerobic stability, fermentative losses, microbial quality, nutrient digestibility.

Posted Date: June 8th, 2021

DOI: https://doi.org/10.21203/rs.3.rs-569714/v1

License: (c) (1) This work is licensed under a Creative Commons Attribution 4.0 International License.

Read Full License 
5 a Universidade Federal do Sul e Sudeste do Pará, Instituto de Estudos em Desenvolvimento Agrário e Regional, Faculdade de

6 Agronomia de Marabá, Marabá, PA, Brazil

${ }^{\mathrm{b}}$ Faculdade de Ciências Agrarias, Universidade Federal da Grande Dourados, Rodovia Dourados-Itahum, Dourados, Brazil. 79804-970

9 Pirassununga, Brazil. 13635-900

10 d Universidade Federal do Sul e Sudeste do Pará, Instituto de Estudos no Trópico Umido, Faculdade de Zootecnia e Medicina Veterinária,

11 Xinguara, PA, Brazil

$12 *$ Corresponding author: jeffersongandra@unifesspa.edu.br 
14 Enzyme additives have been added to forage at ensiling to improve nutritive value. The aim of this study was to evaluate effects of

15 adding exogenous enzymes to silage on fermentative losses and profile, aerobic stability, chemical composition, in vitro degradation,

16 microbial quality, and nutrients intake and digestibility. Treatments were control (CON); addition of exo-1,4- $\alpha$-glycosidase

17 glucoamylase (GLU; Kerazyme 3035, Kera Nutrição Animal, Bento Gonçalves, Brazil); addition of $\beta$-glucan 4-glucanhydrolase (CEL);

18 and GLU + CEL. Data from the silo experiment were analyzed using PROC MIXED of SAS, with fixed effects of glucoamylase and

19 cellulase, and interaction effect between them. In vivo experiment analyses also included fixed effect of Latin Square and period, and

20 random effect of animal within Latin Square. CEL increased $(\mathrm{P} \leq 0.038)$ gas losses and effluents production, CEL and GLU decreased

$21(\mathrm{P}=0.039) \mathrm{DM}$ recovery compared to control but not differ from GLU+CEL. CEL silage had higher $(\mathrm{P} \leq 0.021)$ starch and crude protein

22 and in vitro digestibility of $\mathrm{DM}$ and $\mathrm{NDF}(\mathrm{P} \leq 0.032)$, while GLU had higher $(\mathrm{P}=0.001)$ ADF. CEL showed lower $(\mathrm{P}=0.012)$ ethanol

23 content and higher $(\mathrm{P}=0.02)$ anaerobic bacteria counts, while GLU showed higher $(\mathrm{P}=0.012)$ lactate concentration and lower $(\mathrm{P} \leq$

24 0.002) counts of bacteria and fungi. Lambs fed with CEL presented higher $(\mathrm{P} \leq 0.012)$ digestibility coefficients for DM, OM, CP and

25 NDF. Decrease on DM recovery indicates no improvements on the nutritive value of silage. On the other hand, cellulolytic enzyme

26 positively affected animal digestion.

27 Keywords: aerobic stability, fermentative losses, microbial quality, nutrient digestibility. 
30 A variety of enzyme additives have been added to forage at ensiling to improve fermentation and the nutritive value of silage. Inclusion

31 of enzyme additives to forage aims to break down plant cell walls at ensiling, which can improve silage fermentation once provide

32 sugars for homofermentative lactic acid bacteria. Besides that, enzymes may also increase the digestibility of cell walls, enhancing the

33 nutritive value of silage (Muck et al., 2018).

34 Cellulase is an enzyme that breaks down cellulose into beta-glucose and short-chain polysaccharides. Cellulase is made up of a complex

35 of several different enzymes, including exoglucanases (also called cellobiohydrolases), endoglucanases, and beta-glucosidases.

36 Fibrolytic enzymes added to silages can increase silage digestibility and decrease aerobic stability, as released sugars are rapidly used

37 by spoilage yeasts and molds (Kung and Muck, 2015). Cellulolytic enzymes may act on the more-digestible components of NDF, leaving

38 indigestible components intact what reduces the overall digestibility of consumed NDF (Nadeau et al., 2000; Dehghani et al., 2012; Jin

39 et al., 2015).

40 Glucoamylases are amylolytic enzymes considered exoamylases, which cleave 1,4- $\alpha$-glycosidic bonds from the nonreducing end of the 41 glycosidic chains releasing d-glucose. Thus, these enzymes can increase the content of fermentable carbohydrates and reduce the 
nonfermentable dextrins (Oliveira et al., 2019). Glucoamylase (1,4- $\alpha$-D-glucan glucohydrolase) is extensively used to hydrolyze starch

44 The addition of amylolytic and cellulolytic enzymes to silage with a high content of starch and NDF, such as corn whole plant, can favor the fermentation process, increasing the digestibility of starch and fiber. We hypothesized that the inclusion of amylolytic and cellulolytic enzymes simultaneously in whole plant corn silage improves the fermentation process and animal digestion. This trial aimed to evaluate

47 the effects of amylolytic, and cellulolytic enzymes added to whole-plant corn silage on fermentative losses, aerobic stability, nutritional value, fermentative profile, microbiological population, and animal intake and digestion.

\section{MATERIALS AND METHODS}




\section{Harvesting, Treatments and Ensiling}

Whole plant corn silage (hybrid corn DKB 353 DEKALB $^{\mathrm{TM}}$ ) was produced in a 5ha experimental field divided in 20 locations, until reaching at $105 \mathrm{~d}$. Approximately $100 \mathrm{~kg}$ of whole corn plant from each location was manually harvested (ground level) and chopped to a theoretical cut of $10 \mathrm{~mm}$ using a stationary cutter. Samples (1,000 g) of chopped corn plant were assessed for contents of DM (method 950.15), ash (method 942.05), OM (DM - ash), CP (N × 6.25; method 984.13), and ether extract (EE; method 920.39) according to AOAC International (2000; Table 1). Neutral detergent fiber, acid detergent fiber, and lignin (sulfuric acid method) were determined according to Van Soest et al. (1991). Net energy content of lactation was calculated NRC (2001).

Four treatments in a factorial arrangement were randomly assigned to 40 experimental silos (plastic buckets, $30 \mathrm{~cm}$ height, and $30 \mathrm{~cm}$ diameter) equipped with Bunsen valves. Two kilograms of sand was placed in the bottom of the buckets and covered with a nylon mesh screen $(500 \mu \mathrm{m})$ to drain effluents. Inoculant and chitosan were applied individually to forage assigned for each bucket to generate true replications. Forage was added to the buckets at a compaction rate of $600 \mathrm{~kg} / \mathrm{m}^{3}$ and silos were sealed, weighed, and stored at room temperature $\left(24.6 \pm 2.7^{\circ} \mathrm{C}\right.$; mean $\left.\pm \mathrm{SD}\right)$ for $60 \mathrm{~d}$.

Treatments consisted of no enzymes (control; CON); $300 \mathrm{ml}$ of fresh forage of exo-1,4- $\alpha$-glycosidase glucoamylase, obtained from a selected strain of Aspergillus niger, enzymatic activity 300 U / mL (GLU; Kerazyme 3035, Kera Nutrição Animal, Bento Gonçalves, Brazil); $300 \mathrm{ml}$ of fresh forage of $\beta$-glucan 4-glucanhydrolase, obtained from a selected strain of Trichoderma reesei (CEL; Kerazyme 3035, Kera Nutrição Animal, Bento Gonçalves, Brazil); and GLU + CEL. All treatments were inoculated with microbial 


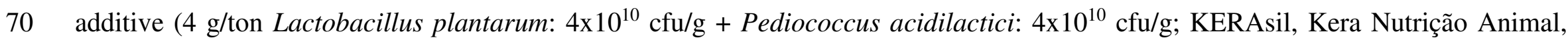

71 Bento Gonçalves, Brazil). Microbial inoculant was diluted in water (2 g/L) and sprayed on the forage, according to manufacturer's

72 information (https://www.kerabrasil.com.br/laminas/Kerasil.pdf).

$74 \quad$ Fermentative Losses

After 70 days of fermentation, mini silos were weighed to calculated gas losses. Effluent losses were calculated based on the

76 difference between weight of silo assembly (plastic bucket, nylon screen, and sand layer) before the storage and weight of silo assembly

77 (plastic bucket, nylon screen, and sand layer containing silage effluent) after $60 \mathrm{~d}$.

The gas losses, effluent losses and dry matter recovery were calculated according to Jobim et al. (2007), as follows:

$$
G L\left(\frac{g}{k g} D M\right)=\frac{S W E(g)-S W O(g)}{D M E(k g)}
$$
in which: SWE is the silo weight at the ensiling, SWO is silo weight at the opening, and DME is total DM ensiled.

$$
E P\left(\frac{g}{k g} D M\right)=\frac{W S A O(g)-W S A E(g)}{D M E(k g)}
$$




$$
\operatorname{DMR}\left(\frac{g}{k g}\right)=\frac{D M O(g)}{D M E(k g)}
$$

in which: DMO is total DM after the opening of silo $(\mathrm{kg})$ and DME is total DM before the ensiling $(\mathrm{kg})$.

\section{Silage Aerobic Stability} temperature (Driehuis et al., 2001). During the 5 days period of aerobic stability evaluation, silos were maintained at room temperature

\section{Chemical Composition and In Vitro Degradation}

95 NEL and macro minerals as previously described. Dry matter and NDF in vitro digestibility were determined using filter bags and

96 artificial rumen incubator (TE-150, Tecnal, Piracicaba, Brazil) according to Tilley and Terry (1963) and adapted by Holden (1999). 
Briefly, filter bags with samples were incubated for $48 \mathrm{~h}$ at $39^{\circ} \mathrm{C}$ in a buffer-inoculum solution $(1,600 \mathrm{~mL}$ of buffer solution and 400 $\mathrm{mL}$ of rumen inoculum). Jars containing the buffer-inoculum solution were purged with $\mathrm{CO}_{2}$ and lids had gas relief valves. After the incubation period, the buffer-inoculum was drained from the jars and the filter bags were gently squeezed against the sides of jar to remove the gas trapped in inflated bags. Afterward, bags were rinsed in jars with 3 changes of warm tap water.

\section{Fermentative Profile}

Silage liquid was extracted from forage samples using a hydraulic press and $\mathrm{pH}$ was measured using a digital potentiometer (MB-10, Marte, Santa Rita do Sapucai, Brazil). Silage liquid aliquots (2 mL) were mixed with $1 \mathrm{~mL}$ of sulfuric acid (1 $\mathrm{N}$ ) for determination of ammonia nitrogen concentration through the colorimetric method described by Foldager (1977).

Volatile fatty acids, ethanol, and lactic acid concentrations in silage juice were determined at the Department of Applied Chemistry of Federal University of Sao Carlos (Araras, Brazil) according to the methods described by Rodrigues et al. (2012). Briefly, aliquots $(1 \mathrm{~mL})$ of silage juice were mixed with formic acid $(0.2 \mathrm{~mL})$ in amber glass bottles and frozen until analysis. Volatile fatty acids and ethanol concentrations were determined in a gas chromatograph (Focus GC, Thermo Fisher Scientific Inc., Waltham, MA) equipped with an automatic sample injector (model AS-3000, Thermo Fisher Scientific Inc.), a glass column $(2.0 \mathrm{~m} \times 0.5 \mathrm{~cm} 80 / 120$ Carbopack B-DA/4\% Carbowax 20M phase; Sigma-Aldrich, St. Louis, MO), and a flame ionization detector set at $270^{\circ} \mathrm{C}$. The chromatograph oven 
112 and injector temperatures were set to $190^{\circ} \mathrm{C}$ and $220^{\circ} \mathrm{C}$, respectively. Hydrogen was used as the carrier gas flowing at $30 \mathrm{~mL} / \mathrm{min}$. The

113 lactic acid concentration was measured by HPLC (LC-10ADVP Shimadzu HPLC system, Shimadzu Inc., Kyoto, Japan) according to

114 Ding et al. (1995).

\section{Microbiological Quality and Enzymatic Activity}

117 Samples (200 g) from the middle layer within each mini silo were collected at the opening for microbiological population counts.

118 Ten grams from samples were diluted in sterilized sodium chloride solution $(0.9 \%, 90 \mathrm{~mL})$ and a serial dilution was performed.

119 Microorganism counts were carried out in triplicate through decimal dilution series in plates with De Man, Rogosa, Sharpe agar for

120 LAB (Briceño and Martinez, 1995), nutrient agar for aerobic and anaerobic bacteria (48 $\mathrm{h}$ of incubation at $30^{\circ} \mathrm{C}$ ), and potato dextrose

121 agar $\left(120 \mathrm{~h}\right.$ of incubation at $\left.26^{\circ} \mathrm{C}\right)$ for mold and yeast as described by Rabie et al. (1997). The absolute values were obtained as colony-

122 forming units and then log-transformed.

123 For enzymatic activity evaluation, samples $(5 \mathrm{~g})$ were constantly shaked at $100 \mathrm{rpm}$ for $1 \mathrm{~h}$ with distilled water (40 mL). Then,

124 it was filtered through nylon cloth and centrifuged $\left(3000 \times \mathrm{g}\right.$ for $5 \mathrm{~min}$ at $\left.5{ }^{\circ} \mathrm{C}\right)$. The enzymatic activity was determined by adding 0.1

$125 \mathrm{~mL}$ of enzymatic suspension (supernatant) to $0.9 \mathrm{~mL}$ of sodium acetate buffer $(0.1 \mathrm{M}$ and $\mathrm{pH} 5.0)$. The measurement for glucoamylase

126 activity is in accordance with Gandra et al. (2019) and cellulase activity according to Nidetzky and Claeyssens (1994). 
Twelve castrated lambs $(32.4 \pm 2.86 \mathrm{~kg}$ body weight and $6.1 \pm 0.4 \mathrm{mo})$ were assigned to three contemporary $4 \times 4$ Latin square

130 design trial, consisting of 19-d periods, with the last $5 \mathrm{~d}$ for data record and sampling. Diet was formulated for $200 \mathrm{~g}$ average daily gain,

131 using Small Ruminants Nutritional System (SRNS) (Table 2). Lambs within each square were randomly assigned to diets CON, GLU,

132 CEL, and GLU+CEL, previously demonstrated in section 2.1. Silage was produced in $200 \mathrm{~L}$ tubs (3 tubs per treatment). Silages were

133 produced as previously described, microbial inoculant was individually weighted, diluted in water, and manually mixed with whole-

134 plant corn silage. Animals were housed in metabolic cages and fed twice daily, at 0700 and $1300 \mathrm{~h}$, targeting refusals between 10 to

$13515 \%$. Samples of feeds and refusals were collected daily during the sampling period and pooled in a composite sample for chemical

136 analyses.

137 On days 15-17 of each experimental period, total fecal collections were performed through a metabolic cage. The feces were 138 weighed every $24 \mathrm{~h}$ of collection and a $10 \%$ aliquot of each day collection was destined to further analysis of digestibility of dry matter,

139 crude and neutral detergent fiber. Samples of silages, dietary ingredients, orts, and feces were analyzed for DM (method 950.15) and

140 crude protein $(\mathrm{CP}, \mathrm{N} \times 6.25$; Kjeldahl method 984.13) according to AOAC (2000), and for neutral detergent fiber (without sodium

141 sulfite) according to Van Soest et al. (1991). Nutrient digestibility (NuD) was estimated as: 


$$
N u D\left(\frac{g}{k g}\right)=\frac{N u_{\text {intake }}(g)-N u_{\text {Fecal }}(g)}{N u_{\text {intake }}(k g)}
$$

where $N u_{\text {intake }}$ is the nutrient intake and $N u_{\text {Fecal }}$ is the nutrient fecal excretion.

\section{Statistical Analysis}

146 Statistical analysis of silage evaluations were performed using PROC MIXED of SAS (SAS Institute Inc, 2011). Data from the

147 silo experiment were analyzed using the following model:

$$
Y_{i j l}=\mu+G_{i}+C_{j}+G_{i}^{*} C_{j}+e_{i j l}
$$

with $e_{i j} \approx N\left(0, \sigma_{e}^{2}\right)$, where: $Y_{i j}$ is the observed value; $\mu$ is the overall mean; $G_{i}$ is the fixed effect of glucoamylase $(i=1$ and 2$) ; C_{j}$

150 is the fixed effect of cellulase $(j=1$ and 2$), G_{i} * C_{j}$ is the interaction effect of glucoamylase by cellulase and $e_{i j l}$ is the random residual

151 error $(l=1$ to 10$) ; N$ stands for Gaussian deviation; and $\sigma_{e}^{2}$ is the variance of error. The treatment effect was evaluated by analysis of

152 variance with $5 \%$ significance.

153 Data of nutrients intake and digestibility were analyzed according to the following model:

$$
Y_{i j k l m}=\mu+S_{i}+a_{j: i}+G_{k}+C_{l}+G_{k} * C_{l+} P_{m}+e_{i j k l m},
$$


156 effect of Latin Square ( $i=1,2$ and 3); $a_{j: i}$ is the random effect of $j^{\text {th }}$ animal within the $i^{\text {th }}$ Latin Square $(j=1$ to 12$)$; $G_{k}$ is the fixed effect 157 of glucoamylase ( $k=1$ and 2 ); $C_{l}$ is the fixed effect of cellulase ( $l=1$ and 2$) ; G_{k} * C_{l}$ is the interaction effect of glucoamylase by cellulase;

$158 P_{m}$ is the fixed effect of experimental period and $e_{i j k l m}$ is the random experimental error; $N$ stands for Gaussian deviation; $\sigma_{a}^{2}$ is the

159 variance of animals; and $\sigma_{e}^{2}$ is the variance of error. The significance level of 5\% was considered for all statistical analyses.

160

161

\section{RESULTS}

\section{Experiment 1}

Cellulases increased $(P \leq 0.038)$ gas losses and effluents production (Table 3). Interaction effect $(\mathrm{P} \leq 0.039)$ was observed on

164 losses by gases (DM) and total (DM), which was greater for silages treated with cellulases and glucoamylases compared with CON but not differ from GLU+CEL. At the same way, recovery DM was smaller for CEL and GLU compared with CON but not differ from

166 GLU+CEL $(\mathrm{P}=0.039)$.

After aerobic exposure, no differences were observed between silages to measure temperature of all treatments (Table 3). There

168 was no difference in $\mathrm{pH}$ between silages in the first $24 \mathrm{~h}$ of aerobic exposure. Control and GLU silages had higher pH value, since $48 \mathrm{~h}$ 
until the end of evaluation period and silages treated with CEL and GLU+CEL showed lower values until the end of oxygen exposure

170 (Figure 1).

Control silages showed lower activities of glucoamylase and cellulases enzymes, as GLU silage for cellulase activity. Silages treated with GLU + CEL showed intermediate activity of both enzyme complexes (Figure 2). higher $(\mathrm{P} \leq 0.032)$ in vitro digestibility of $\mathrm{DM}$ and NDF (Table 4). However, GLU silages presented higher $(\mathrm{P}=0.001)$ ADF and intermediate $(\mathrm{P}=0.003)$ starch content. An interaction effect was observed $(\mathrm{P} \leq 0.007)$ for DM, NDF, NFC and NEL content. CEL and

176 GLU silage showed lower DM and NFC content than CON, but not differ from GLU + CEL silages. Unlike CON silages presented 177 lower NDF content compared with GLU and CEL silages, not differing from GLU + CEL. Additionally, silages treated with cellulases

178 demonstrated higher levels of NEL compared to CON, but not differ to GLU and GLU + CEL.

179 Corn silages treated with cellulases presented lower $(\mathrm{P}=0.012)$ ethanol content and GLU silages showed higher $(\mathrm{P}=0.012)$ 180 lactate concentration (Table 5) and lower $(\mathrm{P} \leq 0.002)$ counts of anaerobic, aerobic, total bacteria, and fungi (Table 6). However, CEL

181 silage presented higher anaerobic bacteria counts $(\mathrm{P}=0.02)$. An interaction effect $(\mathrm{P}=0.003)$ was observed for lactic acid bacteria. 182 GLU+CEL silage showed greater counts than GLU silage, but not differ from CON and CEL.

\section{Experiment 2}


185 greater intake of DM, OM, CP and NDF than those in the GLU + CEL group, but not differ from animals fed CON and GLU silages.

186 For nutrient digestibility, lambs fed CEL silages presented higher $(\mathrm{P} \leq 0.012)$ digestibility coefficients for DM, OM, CP and NDF.

\section{DISCUSSION}

This study hypothesized that inclusion of amylolytic and cellulolytic enzymes simultaneously in whole plant corn silage

190 improves the fermentation process and animal digestion. Enzymes additives showed a significative response on fermentation, mainly

191 because glucoamylase increased lactic acid concentration. But the decrease on DM recovery indicates no improvements on the nutritive

192 value of corn silage. Besides that, cellulolytic enzyme positively affected animal digestion trough an improvement on digestibility of

193 DM, OM, CP and NDF, while amylolytic had no effects.

194 Enzymes incorporation increased gas and total losses (DM) resulting in 6,31\% drop in DM recovery. CEL increased gas and

195 effluents losses, probably due to enhances on anaerobic bacteria count, as a greater microbial activity in silages treated with enzymes is

196 likely related to increases on the fermentative losses observed in this study. In contrast, despite of greater total losses in GLU treatment,

197 corn silage with GLU showed lower counts of anaerobic, aerobic, total bacteria and fungi. 
199 used by undesirable microorganisms, such as spoilage yeasts and molds (Kung and Muck, 2015). According to Higginbotham et al.

200 (1998) yeasts usually initiate aerobic deterioration, and molds continue the deterioration process, because yeasts grow faster but tolerate

201 less heat than molds. In this study, fungi counts were reduced in GLU and no altered in CEL treatment, consequently no effects on

202 aerobic stability were observed.

Cellulolytic enzyme added to corn silage increased starch and crude protein content and reduced ADF. The last can be related to

204 the increase in the degradation of fiber fractions, which is also confirmed for improvements on in vitro degradation of DM and NDF by

205 CEL. Amylolytic enzyme increased ADF and starch content, with no effects on in vitro degradation. Dry matter content was greater in

206 CON, compared to GLU and CEL, but not differ from GLU + CEL. CEL probably showed a lower dry matter content because of greater

207 effluents losses, but the same was not observed in GLU. This is also observed by Lynch et al. (2015) when adding cellulase and xylanase

208 to corn forage before ensiling alone, causing a decrease on DM recovery in the enzyme-treated silage.

209 Exogenous enzymes hydrolyze complex carbohydrates into different products (malto-, cello-, and xylo-oligosaccharides),

210 supporting growth of fibrolytic microorganisms, which was called cross-feeding mechanism and could cause a synergistic effect between

211 fibrolytic and amylolytic enzymes (Zilio et al., 2019). However, in the present study the combination treatments resulted in no further

212 beneficial effects, which agrees with the low cellulase activity observed on GLU treatment. 
214 Ning et al. (2017), amylolytic enzymes can contributes to starch hydrolysis during the ensiling processes, which can explain the increase 215 on lactic acid concentration. In addition, no effects on silage $\mathrm{pH}$ were observed when adding enzymes to silage, differently from the observed by Lynch et al. (2015) who added cellulase and xylanase to corn forage and showed lower pH and higher WSC after $70 \mathrm{~d}$ of 217 ensiling.

The overwhelming majority of studies with enzymes have applied cellulases and hemicellulases for improve the release of plant

219 cell wall carbohydrates, increasing its availability for LAB to ferment to lactic acid (Muck et al., 2018). However, different than 220 expected, in the present study CEL did not affect LAB count, but increased anaerobic bacteria count and reduced ethanol concentration.

221 Eun et al. (2017) demonstrated that fibrolytic enzymes products could greatly improve forage utilization, but the optimum doses and the 222 activities supplied are critical for achieving this response.

223 Exogenous fibrolytic enzyme products can greatly improve forage utilization (Muck et al., 2018). In fact, lambs fed silages 224 containing CEL had greater total tract digestibility. CEL positive effects on DM and NDF digestibility were somewhat expected, as 225 demonstrated by the in vitro assay. Despite of increases on NDF degradability, which could allow greater voluntary intake by reducing 226 physical fill in the rumen (Dado and Allen, 1995), feed intake was not influenced by adding none of the enzymes. On the other hand, 227 increased NDF degradability could also enhance the energy density of diets and stimulates microbial N production (Oba and Allen, 
228 2000) being economically viable. Thus, the increases in NDF degradation observed in our study have the potential to substantially

229 improve the performance of animals fed diets containing corn silage.

230 Despite of amylolytic enzymes have potential to increase nutrients digestibility by acting on starch-protein matrix, which could 231 enhance microbial attachment and enzymatic digestion of starch granules (Giuberti et al., 2014), no beneficial responses were observed 232 on nutrient intake and digestibility. The same was observed by Lara et al. (2018), evaluating lambs fed corn silage with inoculant alone 233 or in combination with amylolytic enzymes.

234 Enzyme aditives are mostly applied in combination with bacterial inoculants (Muck et al., 2018), as observed in this study, where 235 we added to all treatments microbial aditive composed by Lactobacillus plantarum and Pediococcus acidilactici. These bacteria are 236 common facultative heterofermentative strains, which are commonly associated with reduction on $\mathrm{pH}$ and acetic and butyric acid 237 contents and increases on latic acid contents and DM recovery (Muck and Kung, 1997). The association realized in this study turned it 238 difficult to differentiate between bacterial versus enzyme-mediated ensiling responses.

\section{DECLARATIONS}

\section{Funding (information that explains whether and by whom the research was supported)}

242 The study was supported by Federal University da Grande Dourados 
243 Conflicts of interest/Competing interests (include appropriate disclosures)

244 The authors declare no competing interests.

245 Ethics approval (include appropriate approvals or waivers)

246 All the procedures in the present study involving animals were in accordance with the Animal Ethics Committee of the Federal

247 University of Grande Dourados, Brazil, number 0285/2017.

248 Consent to participate (include appropriate statements)

249 Not applicable

250 Consent for publication (include appropriate statements)

251 All the authors give consent for publication

252 Availability of data and material (data transparency)

253 All data generated and analyzed during this study are included in this published article

254 Code availability (software application or custom code)

255 Not applicable

256 Authors' contributions (optional: please review the submission guidelines from the journal whether statements are

257 mandatory) 

approved the final manuscript.

\section{REFERENCES}

261 AOAC International, 2000. Official Methods of Analysis, $17^{\text {th }}$ et, AOAC International, Arlington, VA.

262 Briceño, A. G., and Martínez, R., 1995. Comparison of methods for the detection and enumeration of lactic acid bacteria, Archivos 263 Latinoamericanos de Nutrición, 45, 207-212.

264 Dado, R.G., and Allen, M.S., 1995. Intake limitations, feeding behavior, and rumen function of cows challenged with rumen fill from 265 dietary fiber or inert bulk, Journal of Dairy Science, 78, 118-133.

266 Dehghani, M. R., Weisbjerga, M. R., Hvelplunda, T., and Kristensen, N. B., 2012. Effect of enzyme addition to forage at ensiling on 267 silage chemical composition and NDF degradation characteristics, Livestock Science, 150, 51-58.

268 Ding, M.Y., Koizumi, H., and Suzuki, Y., 1995. Comparison of three chromatographic systems for determination of organic acids in 269 wine, Analytical Sciences, 2, 239-243,

270 Driehuis, F., Oude Elferink, W. H., and Van Wikselaar, P. G., 2001. Fermentation characteristics and aerobic stability of grass silage 271 inoculant with Lactobacillus buchneri, with or without homofermentative lactic acid bacteria. Grass and Forage Science, 56(4), 330272343.

273 Eun, J. S., Beauchemin, K. A., and Schulzet, H., 2007. Use of exogenous fibrolytic enzymes to enhance in vitro fermentation of alfafa 274 hay and corn silage, Journal of Dairy Science, 90, 1440-1451.

275 Foldager, J., 1977. Protein requirement and non-protein nitrogen for high producing cow in early lactation. Ph.D. thesis, East Lasing 276 Michigan State University.

277 Gandra, J. R., Takiya, C. S., Del Valle, T. A., Orbach, N. D., Ferraz, I. R., Oliveira, E. R., Goes, R. H. T. B., Gandra, E. R. S., Pereira, 278 T. L., Batista, J. D. O., Araki, H. M. C., Damiani, J., and Escobar, A. Z., 2019. Influence of a feed additive containing vitamin B12 and 
yeast extract on milk production and body temperature of grazing dairy cows under high temperature-humidity index environment,

280 Livestock Science, 221, 28-32.

281 Giuberti, G., Gallo, A., Masoero, F., Ferraretto, L. F., Hoffman, P. C., and Shaver, R. D., 2014. Factors affecting starch utilization in 282 large animal food production system: A review, Starch, 66, 72-90.

283 Higginbotham, G. E., Mueller, S. C., Bolsen, K. K., and Peters, E. J., 1998. Effects of inoculants containing propionic acid bacteria on fermentation and aerobic stability of corn silage, Journal of Dairy Science, 81, 2185-2192.

285 Holden, L.A., 1999. Comparison of methods of in vitro dry matter digestibility for ten feeds, Journal of Dairy Science, 82, $1791-1794$.

286 Jin, L., Duniere, L., Lynch, J. P., McAllister, T. A., Baah, J., and Wang, Y., 2015. Impact of ferulic acid esterase producing lactobacilli and Technology, 207, 62-74.

Jobim, C. C., Nussio, L. G., and Reis, R. A, 2007. Avanços metodológicos na avaliação da qualidade da forragem conservada. Revista Brasileira de Zootecnia, 36, 101-120.

291 Kung Jr., L., Grieve, D. B., and Thomas, J. W., 1984. Added ammonia or microbial inocula for fermentation and nitrogenous compounds 292 of alfalfa ensiled at various percents of dry matter. Journal of Dairy Science, 67, 299-306.

Kung, L., Jr., and Muck, R. E., 2015. Silage additives: Where are we going? Pages 72-81 in Proc. XVII Int. Silage Conf., Piracicaba, Sao Paulo, Brazil. J. L. P. Daniel, G. Morais, D. Junges, and L. G. Nussio, ed. University of Sao Paulo, Piracicaba, SP, Brazil.

Lara, E. C.; Bragiato, U. C., Rabelo, C. H. S., Messana, J. D., Sobrinho, A. G. S., and Reis, R. A, 2018. Inoculation of corn silage with and meat traits of lambs, Animal Feed Science and Technology, 243, 112-114.

298 Lynch, J. P., Baah, J., and Beauchemin, K. A., 2015. Conservation, fiber digestibility, and nutritive value of corn harvested at 2 cutting 299 heights and ensiled with fibrolytic enzymes, either alone or with a ferulic acid esterase-producing inoculant, Journal of Dairy Science,

$30098,1214-1224$.

301 Muck, R. E.; and Kung Jr, L., 1997. Effects of silage additives ensiling. Pages 187-199 in Proc. Silage: Field to Feedbunk. NRAES-99.

302 Natural Resource, Agriculture, and Engineering Service, Ithaca, NY. 
Muck, R. E.; Nadeau, E. M. G.; Mcallister, T. A.; Contreras-Govea, F. E.; Santos, M. C.; and Kung Jr, L., 2018. Silage review: Recent advances and future uses of silage aditives, Journal of Dairy Science, 101(5), 3980-4000.

Nadeau, E. M. G., Russell, J. R., and Buxton, D. R., 2000. Intake, digestibility, and composition of orchardgrass and alfalfa silages treated with cellulase, inoculant and formic acid for lambs, Journal of Animal Science, 78, 2980-2989.

National Research Council - NRC, 2001, Nutrient requirements of dairy cattle. 7.ed.rev. Washington: National Academy Press, 381p.

Nidetsky, B., and Claeyssens, M., 1994. Specific quantitation of Trichodrema reesel celulases in reconstituted mixtures and its application to cellulase-cellulose binding studies, Biotechnology and Bioengineering, 44, 961-966.

Ning, T., Wang, H., Zheng, M., Niu, D., Zuo, S., and Xu, C., 2017. Effects of microbial enzymes on starch and hemicellulose degradation in total mixed ration silages. Asianaustralas, Journal of Animal Science, 30, 171-180.

Oba, M.; and Allen, M.S., 2000. Effect of brown mibrid 3 mutation in corn silage on productivity of dairy cows fed two levels of dietary NDF: 1. Feeding behavior and nutrient utilization, Journal of Dairy Science, 83, 1333-1341.

Playne, M.J., and McDonald, P., 1966. The buffering constituents of herbage and silage. Journal of Science and Food Agriculture, 17, 264-268.

Rabie, C. J., Lubben, A., Marais, G. J., and Van Vuuren H. J., 1997. Enumeration of fungi in barley, International Journal of Food Microbiology, 35, 117-127.

Rodrigues, P. H. M., Gomes, R. C. G., Meyer, P. M., Borgatti, L. M. O., Franco, F. M. J., and Godoy, G. L. A., 2012. Effects of microbial inoculants and amino acid production by-product on fermentation and chemical composition of sugarcane silage. Revista Brasileira de Zootecnia, 41, 1394-1400.

Tilley, J. M. A., Terry, R.A., 1963. A two-stage technique for the in vitro digestion of forage crops, Grass and Forage Science, 18, 104111.

Van Soest, P. J., Robertson, J. B., and Lewis, B.A., 1991. Methods for dietary fiber, neutral detergent fiber, and nonstarch polysaccharides in relation to animal nutrition. Journal of Dairy Science, 74(10), 3583-3597. 
325

326

327

328
Zilio, E. M. C., Del Valle T. A., Ghizzi L. G., Takiya C. S., Dias M. S. S., Nunes A. T., Silva G. G., and Rennó F. P., 2019. Effects of exogenous fibrolytic and amylolytic enzymes on ruminal fermentation and performance of mid-lactation dairy cows, Journal of Dairy Science, 102, 4179-4189. 
329 Table 1. Chemical composition of the whole corn plant before the ensiling process ( $\mathrm{g} / \mathrm{kg} \mathrm{DM}$, unless stated)

\begin{tabular}{lc}
\hline Item & Diet \\
\hline Dry matter, g/kg as-fed & 254 \\
Organic matter & 939 \\
Neutral detergent fiber & 556 \\
Acid detergente fiber & 327 \\
Starch & 274 \\
Crude Protein & 101 \\
Lignin & 56.2 \\
Ether extract & \\
Net energy ${ }^{1}$, Mcal/kg DM & 25.4 \\
Buffering capacity, mEq/kg of DM & 1.72
\end{tabular}

$330 \quad{ }^{1}$ Calculated according with NRC (2001). 
332 Table 2. Ingredients and chemical composition of diets (g/kg DM, unless stated)

\begin{tabular}{|c|c|}
\hline Item & Diet \\
\hline \multicolumn{2}{|l|}{ Ingredients } \\
\hline Corn silage & 750 \\
\hline Corn meal & 120 \\
\hline Whole raw soybean & 100 \\
\hline Mineral mix ${ }^{1}$ & 30.0 \\
\hline \multicolumn{2}{|l|}{ Chemical } \\
\hline Dry matter, $\mathrm{g} / \mathrm{kg}$ as-fed & 427 \\
\hline Organic matter & 918 \\
\hline Neutral detergent fiber & 467 \\
\hline Acid detergent fiber & 257 \\
\hline Crude Protein & 112 \\
\hline Lignin & 65.6 \\
\hline Ether extract & 43.0 \\
\hline Net energy ${ }^{2}$, Mcal/kg & 1.67 \\
\hline
\end{tabular}


337Table 3. Amylolytic and cellulolytic enzymes effects on corn silage fermentation losses and aerobic stability

\begin{tabular}{|c|c|c|c|c|c|c|c|c|}
\hline Item & \multicolumn{4}{|c|}{ Treatments ${ }^{1}$} & $\mathrm{SEM}^{2}$ & \multicolumn{3}{|c|}{ P-value ${ }^{1}$} \\
\hline Gases (fresh) & 12.0 & 17.4 & 39.4 & 23.6 & 0.29 & 0.296 & 0.019 & 0.101 \\
\hline Effluents (kg/ton) & 11.6 & 14.3 & 23.9 & 21.0 & 1.16 & 0.969 & 0.035 & 0.192 \\
\hline Effluents (DM) & 10.6 & 12.2 & 21.8 & 18.7 & 0.11 & 0.638 & 0.038 & 0.223 \\
\hline Total (DM) & $108^{\mathrm{a}}$ & $183^{b}$ & $187^{\mathrm{b}}$ & $167^{\mathrm{ab}}$ & 0.65 & 0.087 & 0.068 & 0.031 \\
\hline Recovery (DM) & $913^{\mathrm{a}}$ & $869^{b}$ & $845^{\mathrm{b}}$ & $873^{\mathrm{ab}}$ & 0.52 & 0.047 & 0.377 & 0.039 \\
\hline Sum $(5 d)$ & 674 & 667 & 666 & 684 & 2.30 & 0.101 & 0.410 & 0.224 \\
\hline Maximum & 32.0 & 32.6 & 30.8 & 31.9 & 0.25 & 0.432 & 0.326 & 0.157 \\
\hline Stability & 28.9 & 31.1 & 28.6 & 29.1 & 3.51 & 0.321 & 0.741 & 0.321 \\
\hline \multicolumn{9}{|c|}{ Hours } \\
\hline Stability & 95.0 & 105 & 112 & 108 & 0.35 & 0.654 & 0.765 & 0.321 \\
\hline
\end{tabular}

$338^{1} \mathrm{CON}$ (control); GLU exo-1,4- $\alpha$-glycosidase glucoamylase (Kerazyme 3035, enzymatic activity $300 \mathrm{U} / \mathrm{mL}$ ); CEL $\beta$-glucan 4339 glucanhydrolase (Kerazyme 5052 enzymatic activity $700 \mathrm{U} / \mathrm{mL}$ ). 
$340{ }^{2}$ SEM (standard error of the mean).

$341^{3}$ Amyloglucosidase effect (GLU); cellulase effect (CEL); amyloglucosidase* cellulase interaction.

342 
343Table 4. Amylolytic and cellulolytic enzymes effects on corn silage chemical composition and in vitro degradation

\begin{tabular}{|c|c|c|c|c|c|c|c|c|}
\hline \multirow{2}{*}{ Item } & \multicolumn{4}{|c|}{ Treatments $^{1}$} & \multirow{2}{*}{$\mathrm{SEM}^{2}$} & \multicolumn{3}{|c|}{ P-value ${ }^{1}$} \\
\hline & $\mathrm{CON}$ & GLU & CEL & GLU+CEL & & GLU & CEL & INT \\
\hline Dry matter & $285^{\mathrm{a}}$ & $264^{\mathrm{b}}$ & $272^{\mathrm{b}}$ & $279^{a b}$ & 0.16 & 0.001 & 0.267 & 0.001 \\
\hline Organic matter & 946 & 941 & 941 & 940 & 0.05 & 0.303 & 0.231 & 0.909 \\
\hline Neutral detergent fiber & $576^{\mathrm{b}}$ & $589^{a}$ & $600^{\mathrm{a}}$ & $582^{\mathrm{ab}}$ & 0.29 & 0.681 & 0.111 & 0.007 \\
\hline Acid detergent fiber & 437 & 457 & 379 & 419.5 & 0.53 & 0.001 & 0.001 & 0.531 \\
\hline Non-fiber carbohydrate & $264^{\mathrm{a}}$ & $249^{b}$ & $227^{\mathrm{b}}$ & $247^{\mathrm{ab}}$ & 0.36 & 0.705 & 0.002 & 0.002 \\
\hline Starch & 207 & 222 & 258 & 241 & 0.31 & 0.003 & 0.021 & 0.761 \\
\hline Crude protein & 81.3 & 83.9 & 88.2 & 86.7 & 0.09 & 0.727 & 0.007 & 0.245 \\
\hline Lignin & 64.4 & 67.4 & 68.8 & 62.6 & 0.14 & 0.547 & 0.388 & 0.839 \\
\hline Fat & 24.9 & 23.8 & 25.8 & 24.2 & 0.04 & 0.121 & 0.434 & 0.774 \\
\hline Net energy (Mcal/kg) & $1.48^{\mathrm{b}}$ & $1.52^{\mathrm{ab}}$ & $1.57^{\mathrm{a}}$ & $1.51^{\mathrm{ab}}$ & 1.01 & 0.432 & 0.001 & 0.006 \\
\hline \multicolumn{9}{|l|}{ In vitro degradation $(\mathrm{g} / \mathrm{kg})$} \\
\hline Dry matter & 487 & 503 & 565 & 556 & 0.87 & 0.849 & 0.024 & 0.654 \\
\hline Neutral detergent fiber & 468 & 497 & 511 & 507 & 0.76 & 0.543 & 0.032 & 0.653 \\
\hline
\end{tabular}

$344{ }^{1} \mathrm{CON}$ (control); GLU exo-1,4- $\alpha$-glycosidase glucoamylase (Kerazyme 3035, enzymatic activity $300 \mathrm{U} / \mathrm{mL}$ ); CEL $\beta$-D-glucan 4-

345 glucanhydrolase (Kerazyme 5052 enzymatic activity $700 \mathrm{U} / \mathrm{mL}$ ).

$346{ }^{2}$ SEM (standard error of the mean). 
$347{ }^{3}$ Amyloglucosidase effect (GLU); cellulase effect (CEL); amyloglucosidase*cellulase interaction. 
349Table 5. Amylolytic and cellulolytic enzymes effects on corn silage fermentation profile

\begin{tabular}{|c|c|c|c|c|c|c|c|c|}
\hline \multirow{2}{*}{ Item } & \multicolumn{4}{|c|}{ Treatments $^{1}$} & \multirow{2}{*}{$\mathrm{SEM}^{2}$} & \multicolumn{3}{|c|}{ P-value ${ }^{1}$} \\
\hline & $\mathrm{CON}$ & GLU & CEL & GLU+CEL & & GLU & CEL & INT \\
\hline $\mathrm{pH}$ & 3.26 & 3.14 & 3.11 & 3.09 & 0.02 & 0.543 & 0.661 & 0.871 \\
\hline $\mathrm{N}-\mathrm{NH}_{3}(\% \mathrm{TN})$ & 3.87 & 3.67 & 3.52 & 3.62 & 0.12 & 0.213 & 0.554 & 0.441 \\
\hline \multicolumn{9}{|l|}{$\mathrm{mmol} / \mathrm{kgDM}$} \\
\hline Ethanol & 2.95 & 2.02 & 1.95 & 2.12 & 0.03 & 0.125 & 0.012 & 0.546 \\
\hline Acetate & 6.56 & 6.04 & 6.01 & 6.13 & 0.15 & 0.554 & 0.554 & 0.441 \\
\hline Propionate & 0.005 & 0.008 & 0.003 & 0.006 & 0.02 & 0.443 & 0.541 & 0.564 \\
\hline Butyrate & 1.02 & 1.08 & 1.00 & 1.02 & 0.01 & 0.441 & 0.442 & 0.551 \\
\hline Lactate & 6.02 & 7.44 & 6.12 & 6.09 & 0.21 & 0.012 & 0.681 & 0.429 \\
\hline
\end{tabular}

$350 \quad{ }_{1}^{1}$ CON (control); GLU exo-1,4- $\alpha$-glycosidase glucoamylase (Kerazyme 3035, enzymatic activity 300 U / mL); CEL $\beta$-D-glucan 4351 glucanhydrolase (Kerazyme 5052 enzymatic activity $700 \mathrm{U} / \mathrm{mL}$ ).

$352{ }^{2}$ SEM (standard error of the mean).

$353{ }^{3}$ Amyloglucosidase effect (GLU); cellulase effect (CEL); amyloglucosidase*cellulase interaction. 
355Table 6. Amylolytic and cellulolytic enzymes effects on corn silage microbial profile

\begin{tabular}{|c|c|c|c|c|c|c|c|c|}
\hline \multirow{2}{*}{ Item } & \multicolumn{4}{|c|}{ Treatments $^{1}$} & \multirow{2}{*}{$\mathrm{SEM}^{2}$} & \multicolumn{3}{|c|}{ P-value ${ }^{1}$} \\
\hline & $\mathrm{CON}$ & GLU & CEL & GLU+CEL & & GLU & CEL & INT \\
\hline \multicolumn{9}{|c|}{$\log _{10}$} \\
\hline Lactics & $7.23^{\mathrm{ab}}$ & $6.60^{\mathrm{b}}$ & $7.41^{\mathrm{ab}}$ & $8.26^{\mathrm{a}}$ & 0.02 & 0.001 & 0.432 & 0.003 \\
\hline Anaerobics & 5.45 & 5.15 & 8.00 & 7.28 & 0.02 & 0.002 & 0.002 & 0.422 \\
\hline Aerobics & $7.72^{\mathrm{a}}$ & $4.00^{c}$ & $6.82^{\mathrm{ab}}$ & $5.00^{\mathrm{b}}$ & 0.01 & 0.001 & 0.434 & 0.021 \\
\hline Total & 7.84 & 6.62 & 7.75 & 8.45 & 0.02 & 0.001 & 0.111 & 0.116 \\
\hline Fungi and molds & 5.26 & 4.80 & 6.08 & 6.08 & 0.03 & 0.001 & 0.881 & 0.431 \\
\hline
\end{tabular}

$356{ }_{1}^{1}$ CON (control); GLU exo-1,4- $\alpha$-glycosidase glucoamylase (Kerazyme 3035, enzymatic activity 300 U / mL); CEL $\beta$-D-glucan 4-

357 glucanhydrolase (Kerazyme 5052 enzymatic activity $700 \mathrm{U} / \mathrm{mL}$ ).

$358{ }^{2}$ SEM (standard error of the mean).

$359{ }^{3}$ Amyloglucosidase effect (GLU); cellulase effect (CEL); amyloglucosidase*cellulase interaction. 
361Table 7. Amylolytic and cellulolytic enzymes effects on sheep dry matter and nutrients intake and digestibility

\begin{tabular}{|c|c|c|c|c|c|c|c|c|}
\hline \multirow{2}{*}{ Item } & \multicolumn{4}{|c|}{ Treatments ${ }^{1}$} & \multirow{2}{*}{$\mathrm{SEM}^{2}$} & \multicolumn{3}{|c|}{ P-value ${ }^{3}$} \\
\hline & $\mathrm{CON}$ & GLU & CEL & GLU+CEL & & GLU & CEL & INT \\
\hline \multicolumn{9}{|l|}{ Intake ( $k g / d a y)$} \\
\hline Dry matter & $1.54^{\mathrm{a}}$ & $1.42^{\mathrm{ab}}$ & $1.65^{\mathrm{a}}$ & $1.38^{\mathrm{b}}$ & 0.69 & 0.765 & 0.632 & 0.034 \\
\hline Organic matter & $1.45^{\mathrm{a}}$ & $1.33^{\mathrm{ab}}$ & $1.54^{\mathrm{a}}$ & $1.22^{\mathrm{b}}$ & 0.96 & 0.732 & 0.564 & 0.033 \\
\hline $\mathrm{NDF}$ & $1.23^{\mathrm{a}}$ & $1.06^{\mathrm{ab}}$ & $1.25^{\mathrm{a}}$ & $1.01^{\mathrm{b}}$ & 0.51 & 0.675 & 0.342 & 0.039 \\
\hline Crude protein & $0.123^{\mathrm{ab}}$ & $0.125^{\mathrm{ab}}$ & $0.169^{\mathrm{a}}$ & $0.106^{\mathrm{b}}$ & 0.05 & 0.732 & 0.498 & 0.043 \\
\hline \multicolumn{9}{|l|}{ Digestibility $(\mathrm{g} / \mathrm{kg})$} \\
\hline Dry matter & 684 & 757 & 772 & 747 & 0.8 & 0.223 & 0.012 & 0.451 \\
\hline Organic matter & 704 & 775 & 790 & 765 & 0.9 & 0.534 & 0.007 & 0.561 \\
\hline $\mathrm{NDF}$ & 687 & 742 & 762 & 742 & 0.9 & 0.431 & 0.009 & 0.453 \\
\hline Crude protein & 564 & 730 & 754 & 747 & 1.0 & 0.341 & 0.011 & 0.548 \\
\hline
\end{tabular}




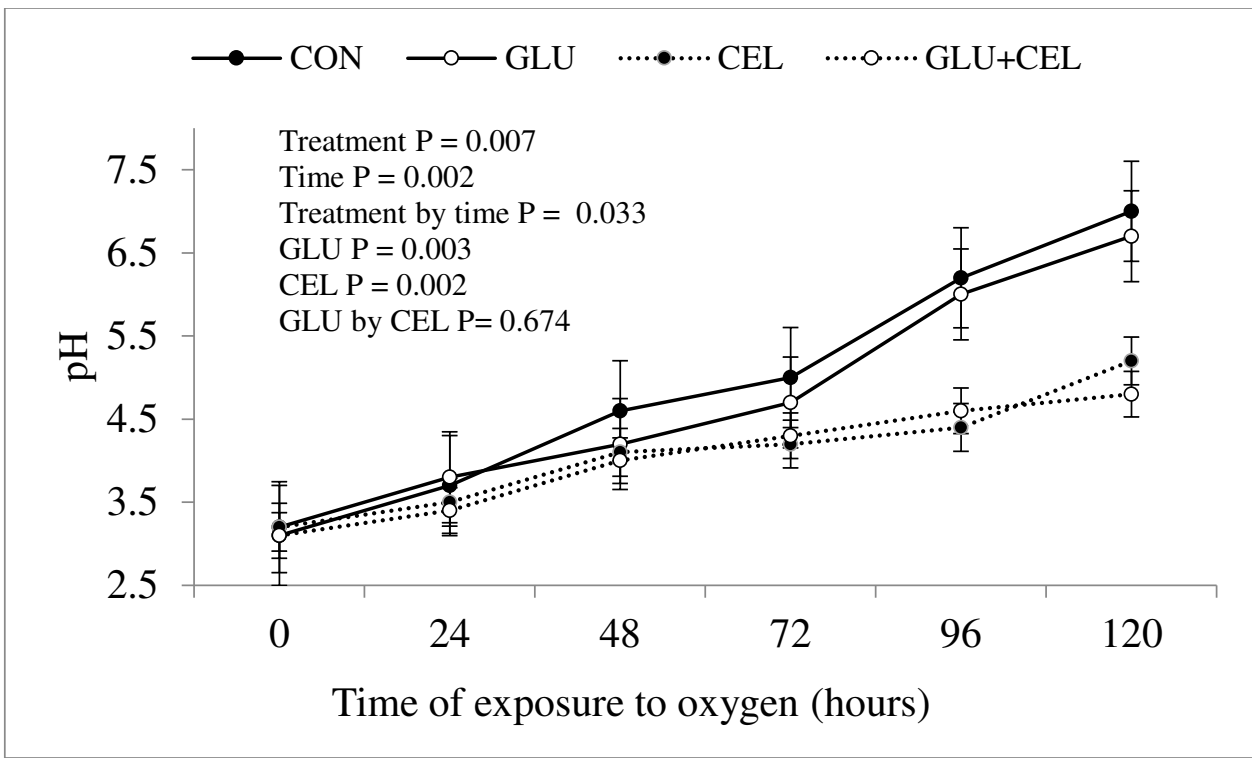

368

369Figure 1. Amylolytic and cellulolytic enzymes effects on corn silage $\mathrm{pH}$ after aerobic exposure 


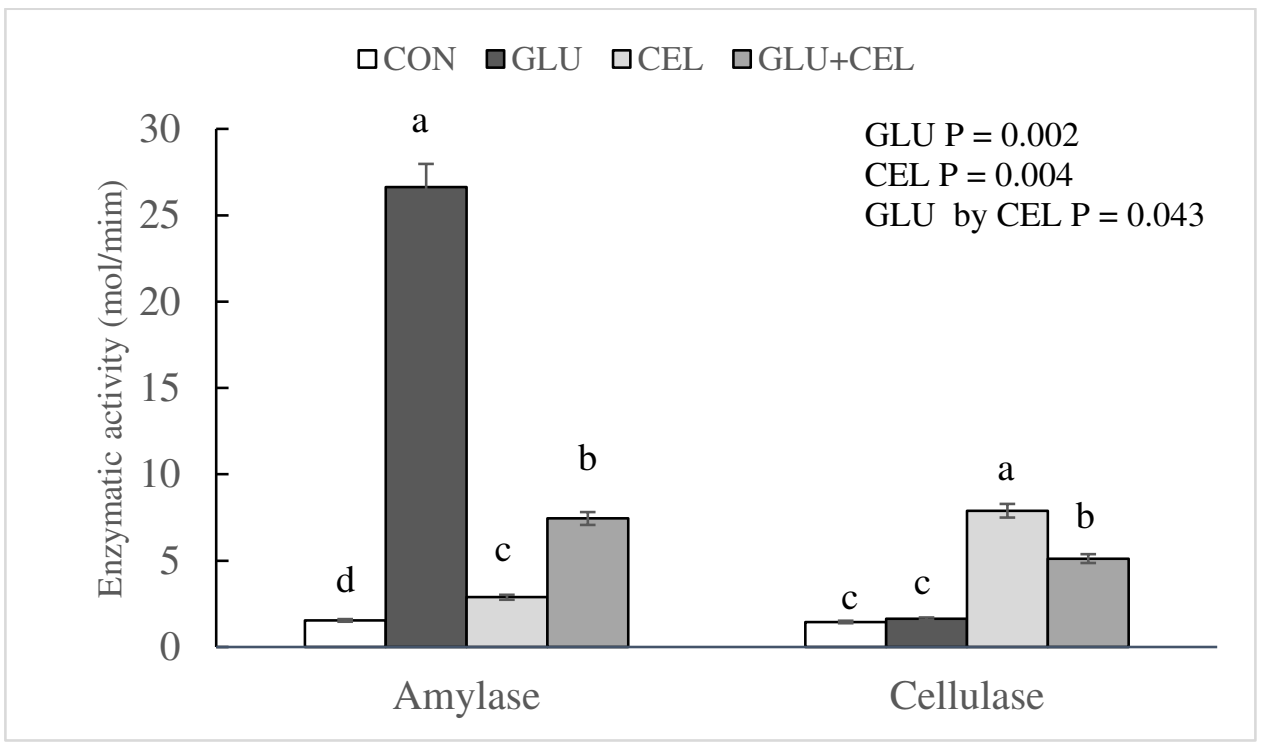

372

373 Figure 2. Amylolytic and cellulolytic enzymes effects on corn enzymatic activity 
Figures

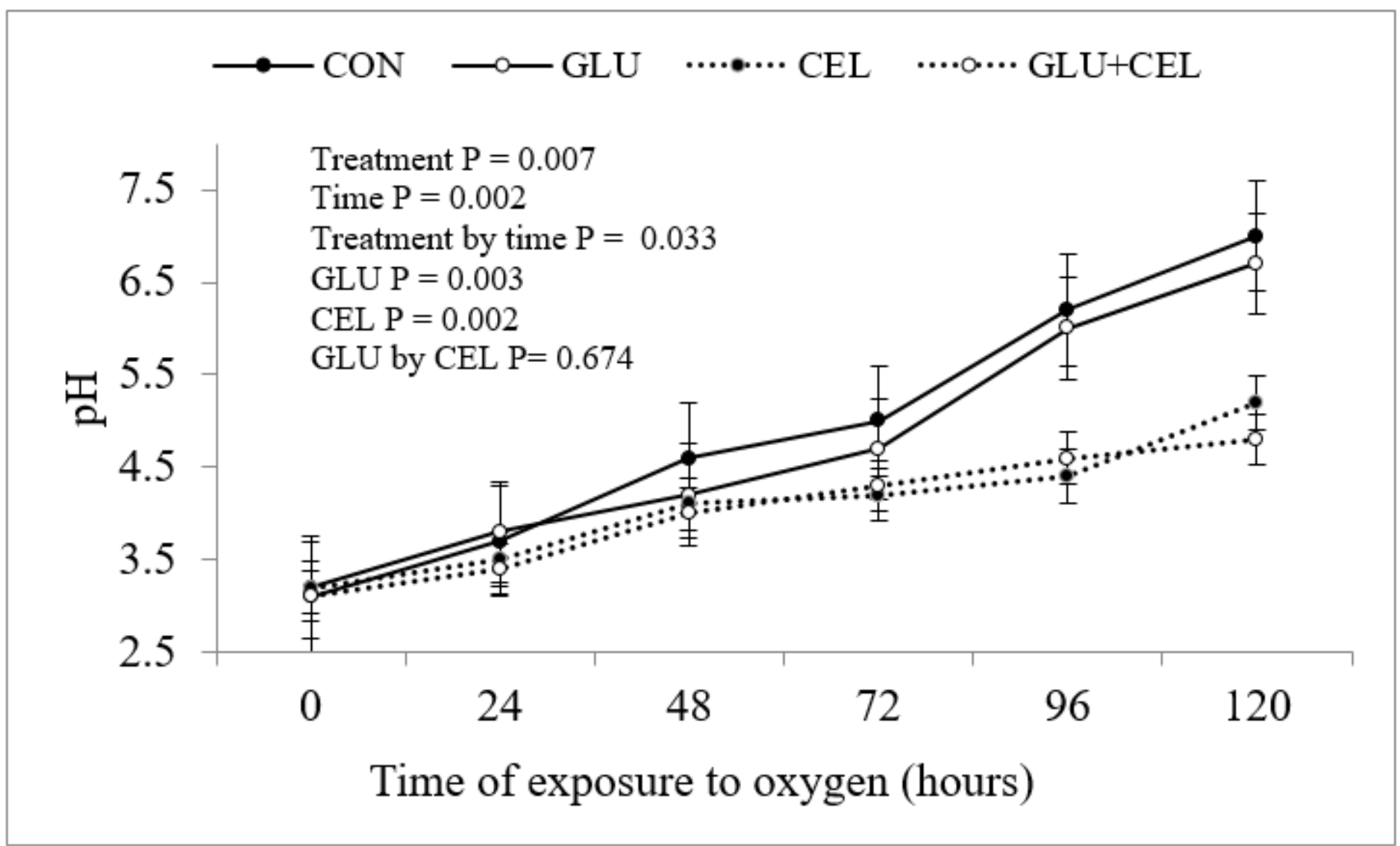

Figure 1

Amylolytic and cellulolytic enzymes effects on corn silage $\mathrm{pH}$ after aerobic exposure 


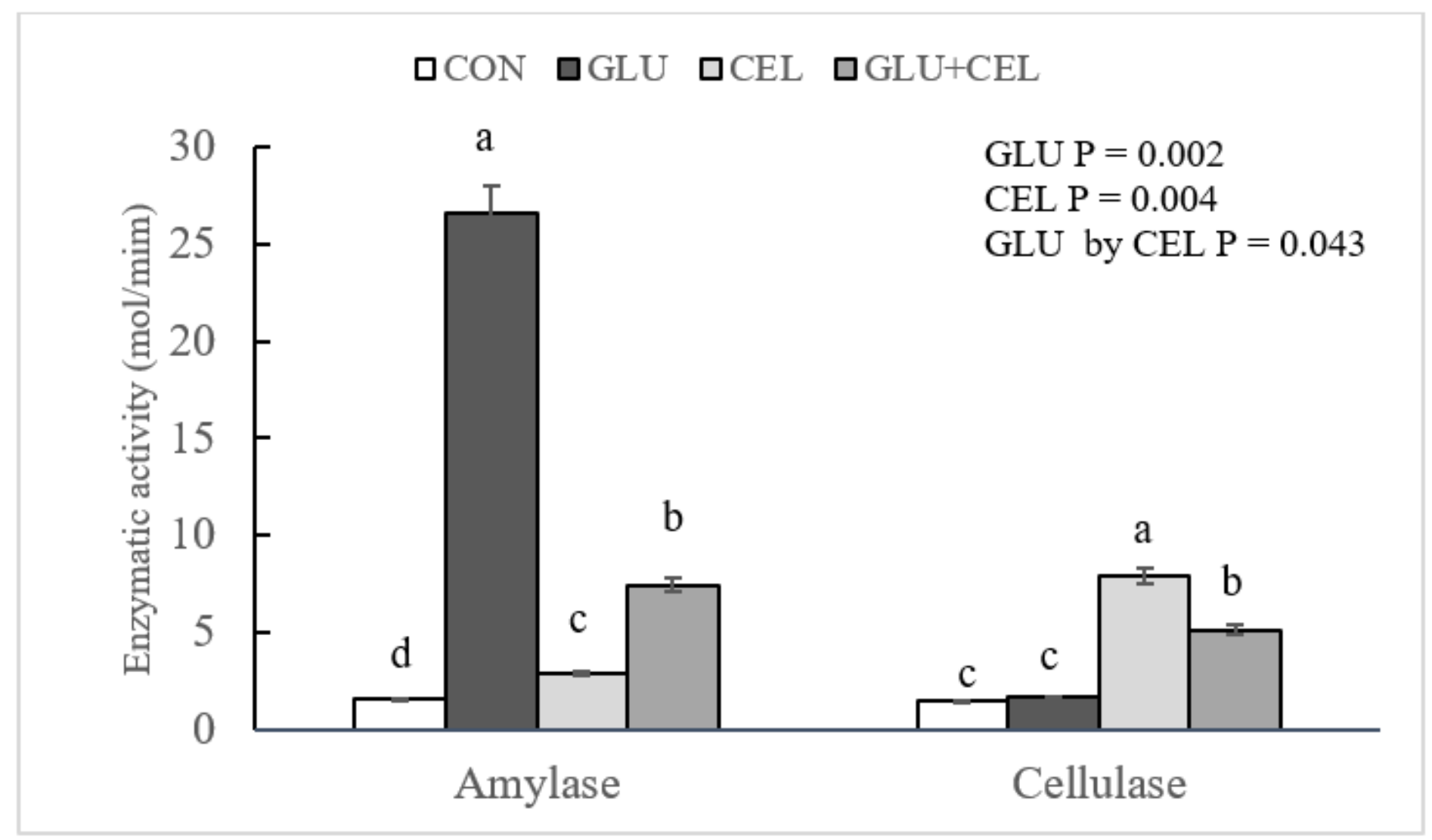

Figure 2

Amylolytic and cellulolytic enzymes effects on corn enzymatic activity 